ORIGINAL SCIENTIFIC PAPER

\title{
Application of NIR spectroscopy in gluten detection as a cross-contaminant in food
}

\author{
Marija Radman, Tamara Jurina, Maja Benković, Ana Jurinjak Tušek, Davor Valinger*, Jasenka Gajdoš Kljusurić \\ University of Zagreb, Faculty of Food Technology and Biotechnology, Pierottijeva 6, Zagreb \\ *Corresponding author: dvalinger@pbf.hr
}

Abstract

The determination of gluten is of critical importance when food screening is intended for special groups such as food ingredient intolerant and allergic persons. Cross-contamination of food that does not contain gluten is also possible in the sales chain. The aim of this study was to determine the applicability of Near-Infrared Spectroscopy (NIRs) for the detection of gluten traces in rice, rice flour, corn flour and corn grits. In the cross-contamination simulation, two types of wheat flour were used. They were added to rice, rice flour, corn flour and corn grits in a range from $5 \%$ to $30 \%$. Apart from the spectra of pure and contaminated samples, conductivity and total dissolved solids were monitored to determine changes in the samples. NIR spectroscopy was combined with chemometric techniques to determine at which wavelengths a glutenfree fingerprint can be detected. Although experiments were carried out with a NIR instrument that monitors molecular vibrations in the range of $\lambda=904-1699 \mathrm{~nm}$, the gluten fingerprint was successfully determined, regardless of the type of flour that was added to the rice, rice flour, corn flour and corn grits. All concentrations of the added flours were successfully determined and models were developed to detect the concentrations of the added flours. Even the conductivity showed good prediction potential in gluten determination. Regardless if the investigated samples were contaminated or not, the determination coefficient $R^{2}$ was over 0.9. Developed models could be used to predict possible wheat flour contamination of any rice or corn product samples or samples prepared for cooking in water.

Keywords: NIR spectroscopy, cross-contamination, gluten, modelling, prediction

Sažetak

Određivanje glutena je od kritične važnosti kada je probir hrane namijenjen posebnim skupinama kao što su netolerantne i alergijske osobe. Križna kontaminacija hrane koja ne sadrži gluten također je moguća u prodajnom lancu. Cilj ovog istraživanja bio je utvrditi primjenjivost blisko-infra crvene spektroskopije (engl. Near Infrared Spectroscopy, NIR) za otkrivanje tragova glutena u riži, rižinom brašnu, kukuruznom brašnu i kukuruznoj krupici. U simulaciji unakrsne kontaminacije korištene su dvije vrste brašna (glatko i oštro) koje je dodano u uzorke u postotku od 5 do 30\%. Osim spektara čistih i kontaminiranih uzoraka, praćena je vodljivost i ukupna otopljena tvar kako bi se odredile promjene u uzorcima. NIR spektroskopija kombinira se s kemometrijskim tehnikama kako bi se odredilo na kojim se valnim duljinama može otkriti otisak prsta glutena. Iako su eksperimenti provedeni s NIR instrumentom koji prat molekularne vibracije u rasponu od $\lambda=904-1699$ nm, uspješno je određen glutenski otisak prsta, bez obzira na vrstu brašna koja je dodana u rižu i uzorcima kukuruza. Sve koncentracije dodanog brašna uspješno su određene i razvijen je model za otkrivanje koncentracije dodanog brašna. Čak je i vodljivost pokazala dobar predikcijski potencijal. Bez obzira na hranu koja je bila kontaminirana ili ne, prosječni $R^{2}$ iznosio je više od 0,9. Razvijeni modeli mogu se koristiti za predviđanje mogućeg onečišćenja rižinog ili kukuruznog brašna pšeničnim brašnom u sirovim uzorcima te također u uzorcima pripremljenim za kuhanje (u vodi).

Ključne riječi: NIR spektroskopija, kros-kontaminacija, gluten, modeliranje, predikcija

\section{Introduction}

Wheat and wheat products are the main sources of gluten that are consumed in large quantities around the globe. Due to their availability, seductive texture and taste, they are consumed daily and can be part of every meal (Čuković-Čavka et al., 2012; Biesiekierski, 2017). In addition to wheat and wheat products, the gluten is present in barley, rye and their products and also in all derivatives and cross-grain varieties obtained from these three cereals (Elli et al., 2017). Gluten is widely used in the food industry due to its properties and may be present in processed food where it is added to maintain moisture and improve the texture and taste of the product
(Biesiekierski, 2017, Čuković-Čavka et al., 2012). For this reason, the source of gluten may also be non-cereal food, e.g. meat products (sausages, honeysuckle); products based on fish and marine organisms (breadded fish sticks); vegetarian substitutes for meat and candies, ice cream, butter, spices and sauces where gluten is used as a thickening agent, an emulsifier or a gelling agent. Furthermore, gluten is increasingly separated from wheat (known as "vital wheat gluten") or from wheat modifications (known as "isolated wheat proteins") to improve the structure of bakery products or for enrichment of low-protein flour (Kucek et al., 2015). According to some authors, the gluten content in the granule ranges from $70 \%$ to $80 \%$ (Scherf et al., 2016; Catassi et al., 2017) and is a com- 
plex mixture of proteins, mostly gliadine and glutenin called prolamines due to the high content of amino acid residues of glutamine (38\%) and proline (20\%) (Biesiekierski, 2017). High proline content makes gluten resistant to degradation of gastrointestinal enzymes and due to that large immunogenic gluten peptides reach the mucosal surface stimulating the development of inflammatory reactions (Čuković-Čavka et al., 2012). Today, it is known that gluten can lead to celiac disease and can also cause a variety of other disorders (Mišak, 2014). According to the consensus of experts published in 2012, the disorders caused by the ingestion of gluten can be divided into three basic forms: autoimmune (celiac disease, dermatitis herpetiformis and gluten ataxia), allergic (wheat allergy) and probably immunologically mediated (gluten hypersensitivity) (Sapone et al., 2012). For celiac patients, a gluten-free diet, which is strict and lifelong, implies a complete exclusion of all foods containing gluten, since even the smallest amounts of gluten can lead to mucosal damage (Sapone et al., 2012; Mišak, 2014). In food processing there is a risk of cross contamination of gluten-free products (HOK, 2016). There is a possibility that the amount of gluten in these products is less than $20 \mathrm{mg} \mathrm{kg}^{-1}$, but there is no "gluten free" label because the products are not tested. Unfortunately, even the "gluten-free" mark is not always a guarantee that the product meets the labelling requirements (Lee et al., 2014). Verma et al. (2017) analysed the gluten content in 200 gluten-free products (including products that naturally do not contain gluten) present in the Italian market. Products that naturally do not contain gluten were contaminated to a greater extent of 16 $\%$ and the labelled gluten-free products to the extent of $9 \%$; where oats were the most contaminated. Research in Canada conducted by Koerner et al. (2011) showed that out of 133 samples of oats, as much as $88 \%$ were contaminated. Lee et al. (2014) analysed 78 samples of food labelled "gluten free" in the United States. Results showed that $20.5 \%$ of samples did not meet the labelling requirements and one of the most commonly contaminated products were breakfast cereals. Near-infrared (NIR) spectroscopy is used in the food industry to control the quality and safety of food. It is routinely used in the composition analysis and functional and sensory analysis of food ingredients, process intermediates and finished products (Gajdoš Kljusurić et al., 2017). The application of NIR spectroscopy for on-line monitoring of industrial processes for the production of various food products from all food groups, is present also in monitoring cereals and cereal products. For example, it is used for determination of proteins, fats and moisture in cookies and cakes, and also for detection of starch, protein, water, ash, colour and grain size in flour (Porep et al., 2015). NIR spectroscopy is also used for monitoring the breadcrumb mixing process, for monitoring cereals and cereal products (Ait Kaddour and Cuq, 2011a), for agglomeration of flour (Aït Kaddour and Cuq, 2011b), for determination of moisture in pasta after extrusion (De Temmerman and sur., 2007) and for determination of moisture and protein in rice and wheat in the wavelength range of $840 \mathrm{~nm}$ to $1048 \mathrm{~nm}(\mathrm{Li}$ et al., 2013).

The most important step in NIR spectroscopy is the development of a good calibration model that includes calculation and regression equation based on the NIR spectrum and known analyte concentration to predict future unknown con- centrations of that analyte in the samples (Badr Eldin, 2011). For the development of the model, the chemometric multivariate analysis methods are used. The most commonly used are: principal component analysis (PCA) and partial squares regression (PLSR) (Ozaki et al., 2007). The aim of this paper was to determine the possibility of using NIR spectroscopy in the qualitative and quantitative detection of gluten as a food contaminant by using of most common chemometric tools related to NIR spectroscopy - PCA and PLSR.

\section{Materials and methods}

The basic objective of the study was to test the possibility of using NIR spectroscopy in gluten detection on 6 basic raw materials (Table 1) which were divided into two groups: Gluten group (Wheat Flour Type 400 and Wheat Flour Type 550) and group that naturally doesn't contain gluten (white long grain rice, rice flour, corn grits and corn flour). Only rice flour $(\mathrm{Rb})$ had the "gluten-free" tag.

Table 1. Raw materials and prepared samples with used abbreviations

\begin{tabular}{|l|c|c|c|}
\hline Sample & $\begin{array}{c}\text { Powder } \\
\text { samples }\end{array}$ & $\begin{array}{c}\text { Liquid } \\
\text { samples } \\
\text { (scanned } \\
\text { with probe) }\end{array}$ & $\begin{array}{c}\text { Liquid } \\
\text { samples } \\
\text { (scanned in } \\
\text { a cuvette) }\end{array}$ \\
\hline Rise & $\mathrm{R}$ & $\mathrm{TR}$ & $\mathrm{KiR}$ \\
\hline Rise flour & $\mathrm{Rb}$ & $\mathrm{TRb}$ & $\mathrm{KiRb}$ \\
\hline Corn grits & $\mathrm{Kk}$ & $\mathrm{TKk}$ & $\mathrm{KiKk}$ \\
\hline Corn flour & $\mathrm{Kb}$ & $\mathrm{TKb}$ & $\mathrm{KiKb}$ \\
\hline Wheat flour, fine & $\mathrm{G}$ & $\mathrm{TG}$ & $\mathrm{KiG}$ \\
\hline $\begin{array}{l}\text { Wheat flour, } \\
\text { coarse }\end{array}$ & $\mathrm{O}$ & $\mathrm{TO}$ & $\mathrm{KiO}$ \\
\hline
\end{tabular}

All the raw material that does not contain gluten $(\mathrm{R}, \mathrm{Rb}$, $\mathrm{Kk}$ and $\mathrm{Kb}$ ) was "contaminated" with fine or coarse flour in $5 \%, 10 \%, 15 \%, 20 \%, 25 \%$ and $30 \%$ ratios. The prepared powder samples were mixed with a wooden stick and their NIR spectra was recorded using a probe. The setup of NIR spectrometer used in this study was previously described in the work of Valinger et al., 2011. After NIR measurements, $25 \mathrm{~mL}$ of water was added to the samples and the suspensions spectra were recorded in the same manner as the previous ones. The experiment plan is presented in the flow chart in figure 1. 


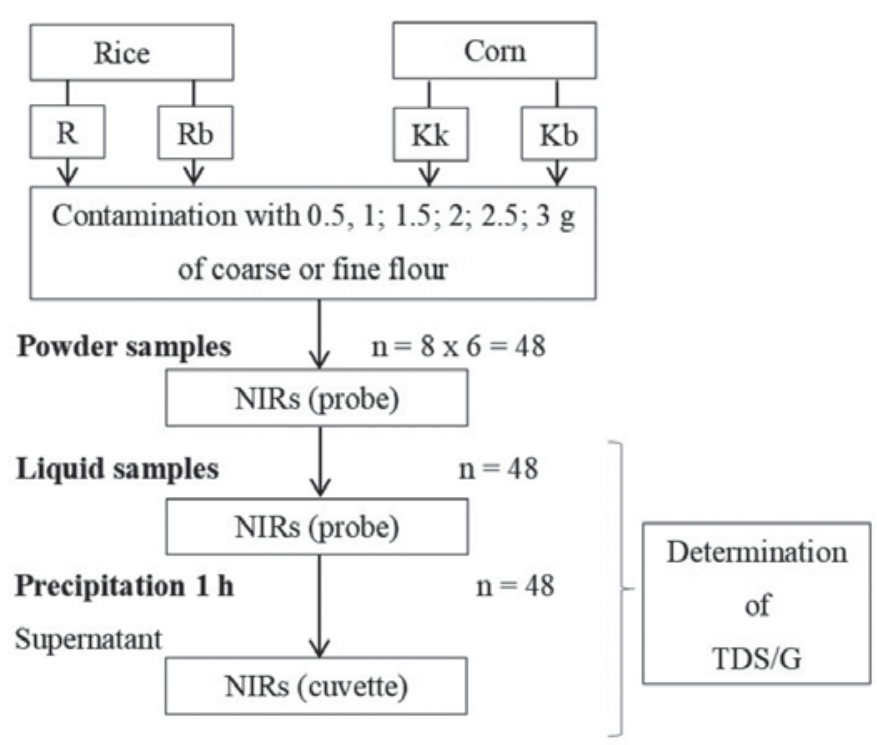

Figure 1. Schematic representation of the process of preparation and measurement of contaminated samples

\section{Light microscopy}

Light microscopy was used to determine the size and shape of the particles in the samples. The Motic B1 Series microscope was used with a mounted Moticam 3 microscopic camera with a magnification of $4 x$. The size and shape of the particles have an impact on the precipitation rate since larger particles settle faster than smaller and spherical particles settle faster than irregularly shaped (Mohammed, 2013).

\section{Determination of moist and dried gluten}

The amount and quality of gluten protein affects the viscous-elastic properties of the dough. In other words, the greater the quantity and the quality of the moist gluten, the obtained dough is more elastic and during fermentation it retains gas and ensures good volume and layout of the baker's cavity (Mlinar et al., 2017).

In $10 \mathrm{~g}$ of wheat flour $5 \mathrm{~mL}$ of a $2 \%$ solution of sodium chloride was added and the mixture was homogenized. The pellet was formed and continuingly flushed with $2 \%$ sodium chloride solution. The wet gluten was divided into two equal pellets that were weighed, and were then dried at $130{ }^{\circ} \mathrm{C}$ for 4 hours. After drying and cooling for one hour, the samples were weighed again.

The percentage of wet and dried gluten in fine and coarse wheat flour was calculated according equations 1 and 2:

[1]

wet gluten $(\%)=\frac{m_{\text {wet gluten }}}{m_{\text {flour }}} \cdot 100$

[2]

dried gluten $(\%)=\frac{\text { wet gluten }(\%) \cdot m_{\text {dried gluten }}}{m_{\text {wet }} \text { gluten }} \cdot 100$

\section{Conductivity and total dissolved substance}

All the ions present in the solution contribute to conductivity, which can be used as a measure of the ion concentrati- on present in the sample. Other parameters, such as total dissolved solids (TDS), can also be determined when measuring conductivity. TDS is a method used to determine the solids in solution since solids are present in most cases as ions (Hanna Instruments, 2017). Conductivity and TDS were measured in triplicate for liquid samples using the conductivity meter (S230 SevenCompact TM). The probe was immersed in the sample and the apparent conductivity was expressed in $\mu \mathrm{S} \mathrm{cm}^{-1}$ and TDS in $\mathrm{mg} \mathrm{L}^{-1}$.

\section{NIR spectroscopy}

NIR spectra of all prepared samples were recorded in the wavelength range from $904 \mathrm{~nm}$ to $1699 \mathrm{~nm}$. NIR spectrometer NIR-128-1.7-USB/6.25/50 $\mu \mathrm{m}$ (Control Development, Inc.) with installed Control Development software SPEC 32 was used for all measurements. The absorbance of the samples was recorded in triplicate. The NIR probe was used for powder samples and the powder samples mixed with water. The cuvette holder was used for recording the supernatants of the samples.

\section{Data processing}

All experimental data obtained by NIR spectroscopy, conductivity, TDS and determination of moisture and dried gluten was used to form a data matrix of 797 columns and 196 rows.

Further data processing was conducted by the XLStat program for qualitative analysis (Principal Component Analysis, PCA) and the program Unscrambler $X$ for the quantitative modelling (Partial Linear Squared Regression, PLSR). The representativeness of the model was assessed based on the coefficient of determination $\left(R^{2}\right)$ and the Ratio of standard error of performance to standard deviation (RPD).

\section{Results and discussion}

Micrographs of the samples were taken to visualise the different particle sizes, primarily of different wheat flour and then the particle size differences in the simulated cross contamination (Figure 2).
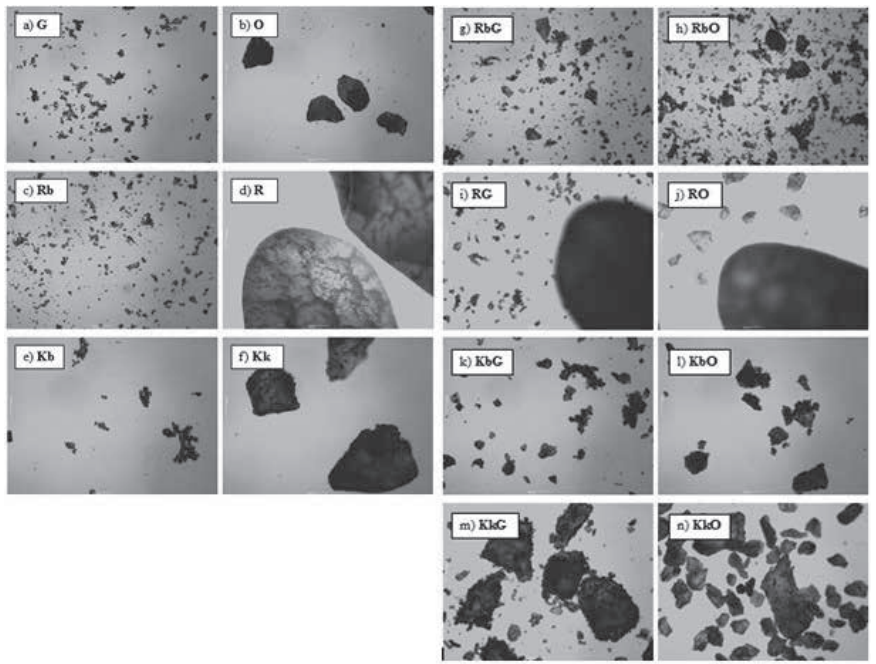

Figure 2. Microscopic images of analysed samples: a) fine wheat flour, b) coarse wheat flour, c) rice flour, d) rice, e) corn flour, f) corn grits, g) rice flour and 
fine wheat flour, $h$ ) rice flour and coarse wheat flour, i) rice and fine wheat flour, j) rice and coarse wheat flour, $k$ ) corn flour with fine wheat flour, l) corn flour with coarse wheat flour, $m$ ) corn grits and fine wheat flour and n) corn grits and coarse wheat flour, taken at $4 x$ magnification

The microscopic images show the irregular shape of the sample particles. Corn grits (compared to flour) had the largest particles $(450 \mu \mathrm{m})$. Hard wheat flour had a particle size about $180 \mu \mathrm{m}$ or less and soft wheat flour and rice flour particle sizes did not exceed $100 \mu \mathrm{m}$.

The content of wet gluten in soft wheat flour was $22.93 \%$ and $19.78 \%$ in hard wheat flour. Ionescu et al. (2010) stated that the wet gluten content in wheat flour ranges from $23 \%$ to $31 \%$ while Kim et al. (2017) indicated a range from $22.4 \%$ to $39.8 \%$ and that the wet gluten content in wheat flour significantly depends on the wheat variety from which the flour was made and the region where wheat is grown.

A change of wet and dried gluten related to different masses of added flour is presented in figure 3 .

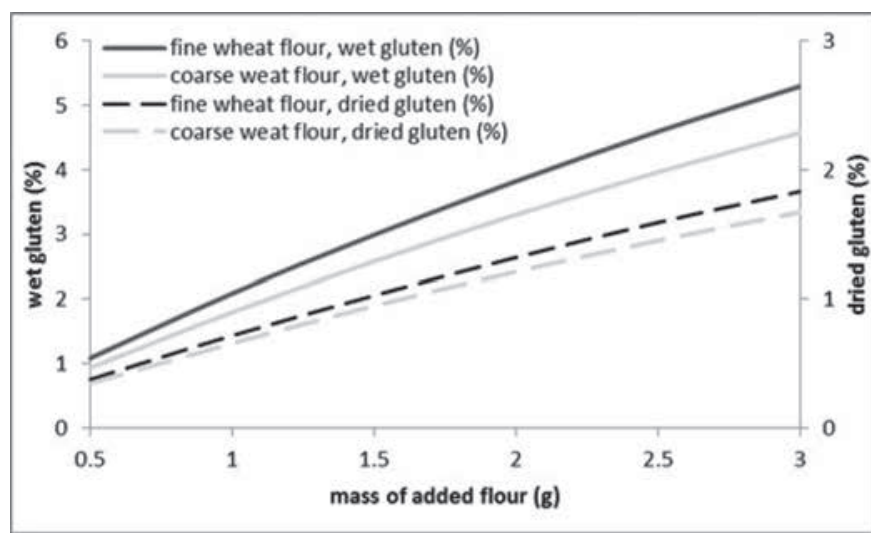

Figure 3. Scatter plot of wet and dried gluten increase based on added amounts of flours.

By gluten drying in case of $3 \mathrm{~g}$ of added flour $5 \%$ of wet gluten was obtained which is in accordance with the literature since the trend of wet and dried gluten is not linear and would be approximately around $12 \%$ for both flours. According to Marti et al. (2015) who tested gluten content in 19 samples of white flour of different wheat varieties gluten content was in range from $8.93 \%$ to $13.44 \%$. According to the increase of gluten content, it was expected to detect a related trend in changes of total dissolved solids (TDS) and conductivity $(\mathrm{G})$ for cross-contaminated foods. Results of those measurements are presented in table 2 .

Table 2. Average values for the total dissolved solids (TDS) and conductivity $(G)$ for cross-contaminated foods

\begin{tabular}{|c|c|c|c|c|c|c|c|c|c|}
\hline \multirow[b]{2}{*}{ measured } & \multirow{2}{*}{$\begin{array}{c}\text { Added } \\
\text { flour (g) }\end{array}$} & \multicolumn{4}{|c|}{ Hard wheat flour addition } & \multicolumn{4}{|c|}{ Soft wheat flour addition } \\
\hline & & rice & $\begin{array}{c}\text { rice } \\
\text { flour }\end{array}$ & $\begin{array}{l}\text { corn } \\
\text { grits }\end{array}$ & $\begin{array}{l}\text { corn } \\
\text { flour }\end{array}$ & rice & $\begin{array}{l}\text { rice } \\
\text { flour }\end{array}$ & $\begin{array}{l}\text { corn } \\
\text { grits }\end{array}$ & $\begin{array}{l}\text { corn } \\
\text { flour }\end{array}$ \\
\hline \multirow[t]{6}{*}{ TDS $\left(\mathrm{mg} \mathrm{L}^{-1}\right)$} & 0.5 & 46.0 & 22.0 & 20.0 & 80.5 & 69.5 & 26.5 & 33.0 & 80.5 \\
\hline & 1.0 & 71.5 & 39.5 & 31.5 & 65.5 & 99.5 & 53.5 & 72.0 & 217.5 \\
\hline & 1.5 & 93.0 & 67.0 & 46.5 & 165.5 & 132.0 & 62.0 & 95.0 & 295.5 \\
\hline & 2.0 & 112.5 & 56.5 & 110.5 & 149.0 & 149.5 & 127.0 & 157.0 & 252.5 \\
\hline & 2.5 & 142.5 & 107.0 & 105.0 & 50.0 & 182.5 & 165.5 & 172.0 & 345.0 \\
\hline & 3.0 & 146.5 & 163.0 & 120.0 & 96.0 & 202.5 & 203.5 & 195.5 & 367.0 \\
\hline \multirow[t]{6}{*}{$\mathbf{G}\left(\mu \mathrm{S} \mathrm{cm}^{-1}\right)$} & 0.5 & 91.0 & 44.0 & 40.0 & 162.5 & 139.0 & 52.5 & 66.0 & 160.0 \\
\hline & 1.0 & 142.5 & 79.0 & 63.0 & 132.0 & 198.5 & 106.5 & 144.0 & 434.5 \\
\hline & 1.5 & 184.5 & 134.0 & 93.0 & 332.5 & 262.5 & 123.5 & 190.0 & 589.5 \\
\hline & 2.0 & 224.0 & 113.0 & 221.0 & 300.0 & 299.0 & 254.0 & 314.5 & 504.0 \\
\hline & 2.5 & 283.5 & 214.0 & 210.0 & 101.0 & 365.0 & 330.5 & 343.5 & 689.5 \\
\hline & 3.0 & 293.0 & 326.0 & 240.5 & 194.0 & 405.0 & 407.0 & 391.5 & 729.5 \\
\hline
\end{tabular}

Measured TDS and G showed an increase in values which is linearly proportional to the added contaminant, regardless which type of flour was used. The lowest TDS value of $22 \mathrm{mg}$ $\mathrm{L}^{-1}$ was observed for the samples in which the minimum of coarse wheat flower was added to rice flour while the highest value of TDS of $367 \mathrm{mg} \mathrm{L}^{-1}$ was observed for samples where fine wheat flour was added to corn flour.
The spectrum of samples recorded with NIR spectroscopy and their similarity and/or differences are presented in figure 4. NIR spectroscopy is based on the absorption of electromagnetic radiation in the range of $780 \mathrm{~nm}$ to $2500 \mathrm{~nm}$ where the tonalities of the higher tones and the combination of overtones appear, among which the most prominent are $\mathrm{OH}, \mathrm{NH}, \mathrm{CH}$ and SH bonds (Ozaki et al., 2007). 

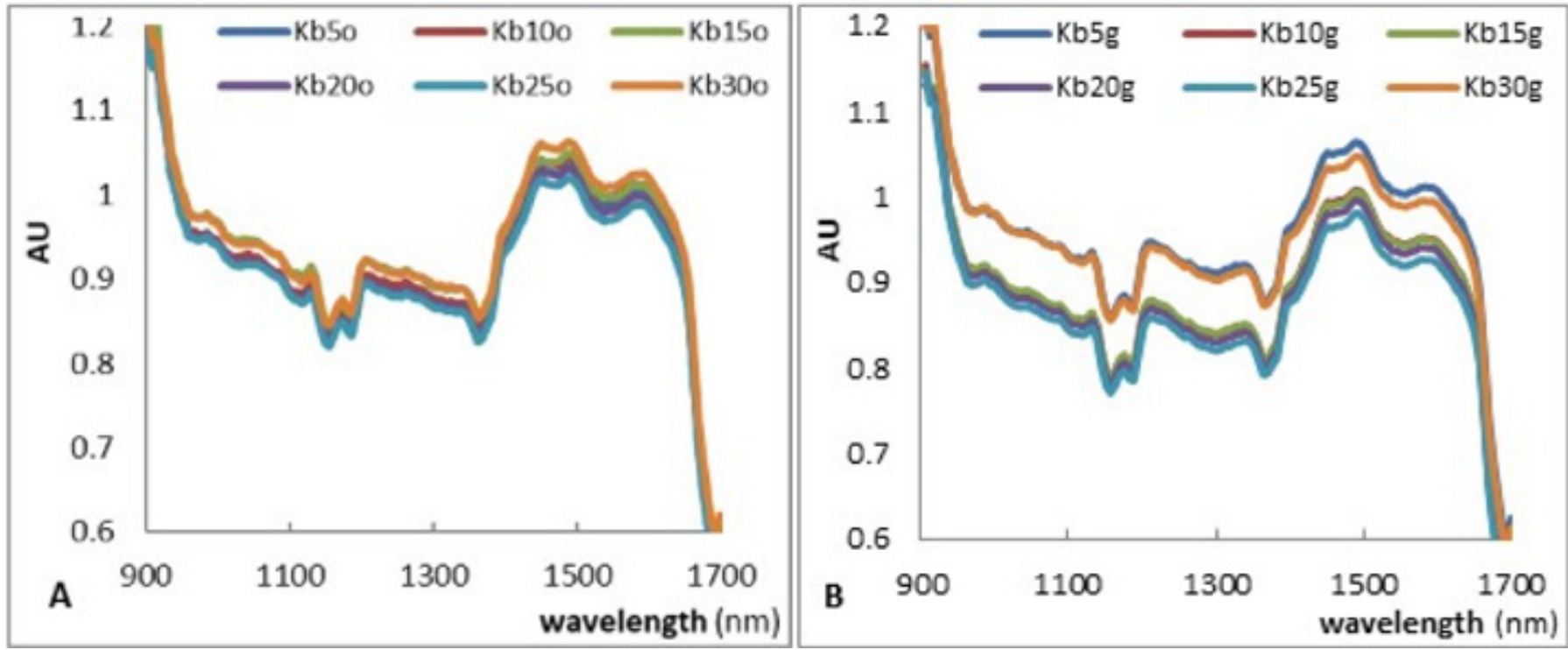

Figure 4. NIR spectrum of powdered corn flour samples contaminated with different percentages of A) coarse wheat flour (5-30 $\%)$ and B) fine wheat flour (5-30\%)

In figure 4 differences between the NIR spectrum of fine and coarse wheat flour can be observed. In addition, the spectrum is characterized by a stronger signal in the wavelength range of about $1400 \mathrm{~nm}$ to $1550 \mathrm{~nm}$ due to water content but also the first overtones of N-H linkages which are characteristic of proteins (Badr Eldin, 2011).

Based on the NIR spectral data, the principal component analysis (PCA) was conducted. This is a chemometric method used to obtain information from chemical data using statistical procedures. PCA enables analysis and grouping of data and presents the qualitative model. The obtained data can be represented by dots in the n-dimensional space where each dimension represents a given variable $\mathrm{x}_{\mathrm{i}}(\mathrm{i}=1,2, \ldots, \mathrm{n})$. By introducing main components (PCs), the dimensionality of space is reduced, which simplifies data interpretation. The first major component (PC1) describes the largest variation in the data, while the rest of the variation is described by other major components ( $\mathrm{PC} 2, \mathrm{PC} 3$ etc.). The distance between projections of the point and the main component of the origin of the coordinate system and the data visualization is performed using factor score (Jednačak and Novak, 2013). In this work Varimax rotation was used without any data pre-processing (Abdi and Williams, 2010).

The results of qualitative effects of PCA are presented in figure 5 .

In Figure 5A grouping formed based on NIR spectra of raw material is presented while in the figure $5 \mathrm{~B}$ grouping of liquid forms of rice flour contaminated with different shares of coarse and fine wheat flour are presented.

In figure 5A clear separation of samples can be observed, with the greatest particle sizes (rice, $\mathrm{R}$ in the $1^{\text {st }}$ quadrant \& corn grits, $\mathrm{Kk}$ in the $2^{\text {nd }}$ quadrant), covering $99.98 \%$ of all data variances. In Figure 5B clear separation of two sample groups can be observed- those contaminated with coarse wheat flour (almost all grouped in the $3^{\text {rd }}$ quadrant) and those contaminated with fine wheat flour.
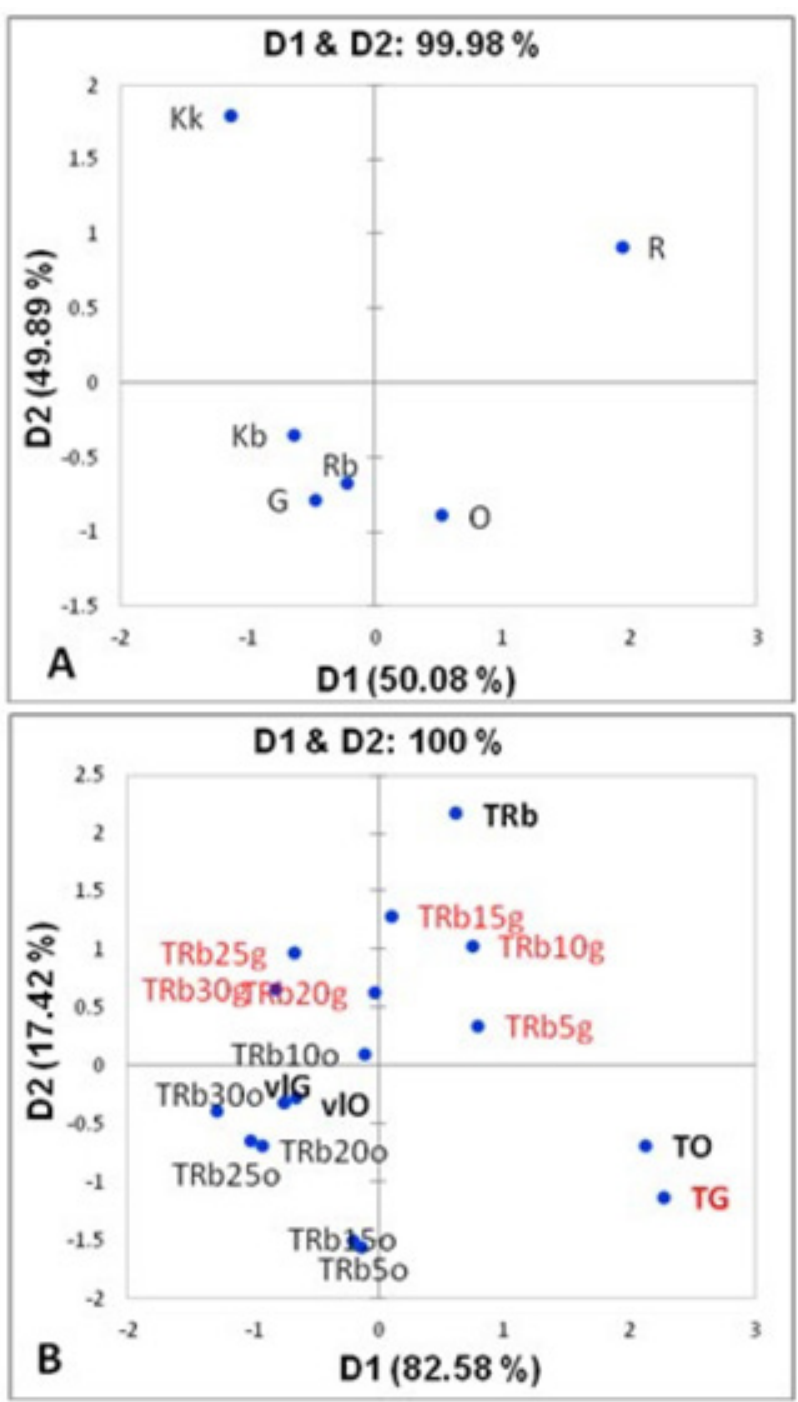

Figure 5. PCA analysis of the NIR spectrum of A) basic raw materials and B) liquid form of rice flour contaminated with soft and hard wheat flour 
PLSRs models were developed for each food sample (rice, rice flour, corn flour and corn grits) for which the NIR spectrum was used as input variable and percentage of added flour, wet gluten (\%), dried gluten (\%), total dissolved solids (TDS) and conductivity (G) were used as outputs variables.

The effectiveness of the PLSRs for quantitative prediction was rated based on the calculated coefficient of de- termination and RPD value. For good models coefficient of determination is expected to be over 0.95 and the ratio of standard error of performance to standard deviation (RPD) is expected to be over 3 (Janči et al., 2017). The efficiency of models based on the NIR spectra with added concentrations of the contaminant (wheat flour) and TDS/G are presented in table 3.

Table 3. Determination coefficient $\left(R^{2} p\right)$ and the Ratio of standard error of performance to standard Deviation (RPD) values for PLSR models

\begin{tabular}{|l|c|c|c|c|c|c|}
\hline \multirow{2}{*}{$\begin{array}{l}\text { Contaminated food\# \& added flour* } \\
\text { (O or G) }\end{array}$} & \multicolumn{2}{|c|}{ concentration } & \multicolumn{2}{|c|}{ TDS } & \multicolumn{2}{c|}{ G } \\
\cline { 2 - 7 } & $\mathrm{R}^{2} \mathrm{p}$ & $\mathrm{RPD}$ & $\mathrm{R}^{2} \mathrm{p}$ & $\mathrm{RPD}$ & $\mathrm{R}^{2} \mathrm{p}$ & $\mathrm{RPD}$ \\
\hline $\mathrm{RG}$ & 0.941 & 4.117 & 0.937 & 3.997 & 0.935 & 3.910 \\
\hline $\mathrm{RO}$ & 0.941 & 4.124 & 0.915 & 3.420 & 0.913 & 3.390 \\
\hline $\mathrm{RbG}$ & 0.958 & 4.880 & 0.891 & 3.022 & 0.890 & 3.019 \\
\hline $\mathrm{RbO}$ & 0.965 & 5.345 & 0.996 & 16.013 & 0.996 & 15.617 \\
\hline $\mathrm{KbG}$ & 0.982 & 7.454 & 0.982 & 7.538 & 0.983 & 7.559 \\
\hline $\mathrm{KbO}$ & 0.989 & 9.535 & 0.996 & 16.013 & 0.996 & 15.617 \\
\hline $\mathrm{KkG}$ & 0.950 & 4.472 & 0.933 & 3.855 & 0.833 & 2.445 \\
\hline $\mathrm{KkO}$ & 0.982 & 7.454 & 0.738 & 1.955 & 0.738 & 1.955 \\
\hline
\end{tabular}

${ }^{*} \mathrm{R}=$ rice; $\mathrm{Rb}=$ Rice flour; $\mathrm{Kb}=$ corn flour; $\mathrm{Kk}=$ corn grits; ${ }^{*} \mathrm{G}=$ fine wheat flour, $\mathrm{O}=$ coarse wheat flour

For the purpose of potential prediction of flour percentage in analysed samples (0-30\%), PLSR models for all combinations of raw materials of powder and liquid samples were created. Out of 24 models (8 combinations and 3 parameters), 3 were not applicable, i.e. they had a coefficient of determination $\left(\mathrm{R}^{2}\right)$ under the value of 0.89 . Although the same patterns for rice samples as the base were developed in both types of samples, the patterns for liquid samples show higher coefficients of determination (can be seen from the TDS and G model parameters). The combinations of rice flour and coarse wheat flour as well as the combination of corn flour with coarse wheat flour $\left(\mathrm{R}^{2}=0.996\right)$ had the highest values of the wheat flour concentration in the samples.

Williams (1987) published a table which gives the following interpretations for various RPD values; from very poor prediction (RPD ranged from $0-2.3$ ) to excellent prediction (RPD > 8.1) but for a real system all RPD over 3 present models with good quantitative prediction odds (Metrohm, 2013). The agreement between predicted and experimental values is shown as the result of PLSR in Figure 6. For the prediction of different concentrations of coarse wheat flour used to contaminate the corn grits based on the NIR spectrum, RPD value of 7.4 was observed even for low contaminant concentrations $(<30 \%)$.

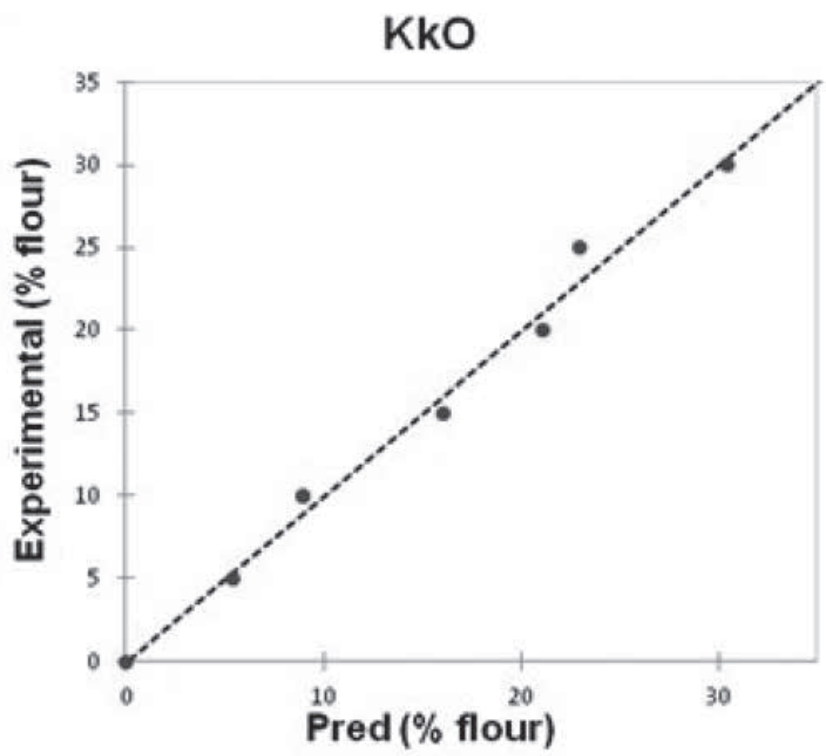

Figure 6. Linear regression model predicting the percentage of coarse wheat flour added to corn grits samples, $R^{2}=0.982, R P D=7.454$ 


\section{Conclusions}

Only NIR spectroscopy of all samples recorded in the wavelength range of $904 \mathrm{~nm}$ to $1699 \mathrm{~nm}$ (rice, rice flour, corn grits \& corn flour contaminated with different percentages of fine and coarse wheat flour (5-30\%), were poorly informative in finding the differences among them due to poor absorption and overlapping of absorbing curves. The application of multivariate tools as PCA and PLS helped in the qualitative and quantitative differentiation of the measured samples. The quantitative analysis of sample differentiation was successful when the principal component analysis (PCA) was used. Application of the PCA resulted with differentiation of samples based on the food as well as on the added wheat flour. The PLSRs showed very good prediction possibilities (RPD $>3$ ) for $87.5 \%$ of all observed parameters and contaminated samples.

It has been found that by increasing the weight of wheat flour added to liquid samples of rice, rice flour, corn grits and corn flour, linear increase in conductivity values and TDS was observed. The exception was a combination of maize and coarse wheat flour where conductivity values and TDS are decreasing after addition of 2 or more grams. The strongest linear relationship was shown with rice and corn grits specimens, including samples of corn flour with fine wheat flour $\left(R^{2}>0.98\right)$ and samples of coarse wheat flour $\left(R^{2}>0.93\right)$. Gluten contamination is possible in foods that naturally do not contain gluten, and even in foods with the term "gluten-free" on the declaration. This is a major problem and endangers the health of people with the only cure-free diet. Although in this study no samples of gluten meeting the "gluten-free" $(<20$ $\left.\mathrm{mg} \mathrm{kg}^{-1}\right)$ and "very low gluten content" $\left(<100 \mathrm{mg} \mathrm{kg}^{-1}\right)$ were tested, the results obtained could be of benefit to future research which will deal with the construction of more sensitive and better calibration models for the detection of gluten as a food contaminant by NIR spectroscopy.

\section{References}

Abdi, H., Williams, L. J. (2010) Principal Component Analysis. WIREs Computational Statistics, 2 433-459.

Aït Kaddour, Cuq, B. (2011a) Dynamic NIR spectroscopy to monitor bread dough mixing: a short review. American Journal of Food Technology, 6 173-185.

Aït Kaddour, Cuq, B. (2011b) Dynamic NIR spectroscopy to monitor wheat product processing: a short review. American Journal of Food Technology, 6 186-196.

Badr Eldin, A. (2011) Near Infra Red Spectroscopy. U: Wide Spectra of Quality Control, (Akyar, I., ured.), InTech, Rijeka, str. 238-248.

Biesiekierski, J. R. (2017) What is gluten? Journal of $G a-$ stroenterology and Hepatology, 32 78-81.

Catassi, C., Fabiani, E., Iacono, G., D'Agate, C., Francavilla, R., Biagi, F., Volta, U., Accomando, S., Picarelli, A., De Vitis, I., Pianelli, G., Gesuita, R., Carle, F., Mandolesi, A., Bearzi, I., Fasano, A. (2007) A prospective, double-blind, placebo-controlled trial to establish a safe gluten threshold for patients with celiac disease. American Journal of Clinical Nutrition, 85 160-166.
Čuković-Čavka, S., Crnčević Urek, M., Brinar, M., Turk, N. (2010) Celijakija u odrasloj dobi. Medicus, 21 179-186.

De Temmerman, J., Saeys, W., Nicolaï, B., Ramon, H. (2007) Near infrared reflectance spectroscopy as a tool for the in-line determination of the moisture concentration in extruded semolina pasta. Biosystems Engineering, 97 313-321.

Elli, L., Villalta, D., Rancoroni, L., Barisani, D., Ferrero, S., Pellegrini, N., Bardella, M. T., Valiante, F., Tomba, C., Carroccio, A., Bellini, M., Soncini, M., Cannizzaro, R., Leandro, G. (2017) Nomenclature and diagnosis of gluten-related disorders: A position statement by the Italian Association of Hospital Gastroenterologists and Endoscopists (AIGO). Digestive and Liver Disease, 49 138-146.

Gajdoš Kljusurić, J., Valinger, D., Jurinjak Tušek, A., Benković, M., Jurina, T. (2017) Application of Near Infrared Spectroscopy (NIRs), PCA and PLS models for the analysis of dried medicinal plants. U: Science within Food: Up-to-date Advances on Research and Educational Ideas, (Méndez-Vilas, A., ured.) Formatex Research Center, Badajoz, str. 28-35.

Hanna Instruments (2017) Električna vodljivost, <http:// hannainst.hr/elektricna-vodljivost $>$. Pristupljeno 29. svibnja 2018.

HOK (2016) Vodič za označavanje nepretpakirane hrane. HOK - Hrvatska obrtnička komora, Zagreb.

Ionescu, V., Stoenescu, G., Vasilean, I., Aprodu, I., Banu, I. (2010) Comparative evaluation of wet gluten quantity and quality through different methods. Fascicle IV-Food Technology, 34 44-48.

Jednačak, T., Novak, P. (2013) Procesne analitičke tehnike temeljene na vibracijskoj spektroskopiji in-line i primjena $\mathrm{u}$ industriji. Kemija u Industriji, 62 71-80.

Kim, M. J., Kwak, H. S., Jung, H. Y., Lee, M. J., Kim, O. W., Kim, H., Kim, S. S. (2017) Consumer perception of bread depending on wheat origin in relation to physicochemical characteristics of wheat flour. Emirates Journal of Food and Agriculture, 29 351-358.

Koerner, T. B., Cleroux, C., Poirier, C., Cantin, I., Alimkulov, A., Elamparo, H. (2011) Gluten contamination in the Canadian commercial oat supply. Food Additives \& Contaminants, 28 705-710.

Kucek, L. K., Veenstra, L. D., Amnuaycheewa, P., Sorre1ls, M. E. (2015) A grounded guide to gluten: how modern genotypes and processing impact wheat sensitivity. Comprehensive Reviews in Food Science and Food Safety, 14 285-302.

Lee, H. J., Anderson, Z., Ryu, D. (2014) Gluten Contamination in Foods Labeled as „Gluten Free“ in the United States. Journal of Food Protection, 77 1830-1833.

Li, R., Kawamura, S., Fujita, H., Fujikawa, S. (2013) Near-infrared spectroscopy for determining grain constituent contents at grain elevators. Employee Assistance European Forum, 6 20-26.

Marti, A., Augst, E., Cox, S., Koehler, P. (2015) Correlations between gluten aggregation properties defined by the GlutoPeak test and content of quality-related protein fractions of winter wheat flour. Journal of Cereal Science, 66 89-95.

Metrohm (2013) NIR Spectroscopy - a guide to near-infrared spectroscopic analysis of industrial manufacturing processes, Metrohm AG, Herisau.

Mišak, Z. (2014) Gluten u prehrani: uzrok celijakije ili nešto više. Paediatria Croatica, 58 175-179. 
Mlinar, R., Ikić, I., Jukić, K., Maričević, M., Bukan, M. (2017) Bc Mandica - nova sorta ozime pšenice. Sjemenarstvo, $3035-43$.

Mohammed, M. A. R. (2013) Studying the factors Affecting the Settling Velocity of Solid Particles in Non-Newtonian Fluids. Nahrain University, College of Engineering Journal, $1641-50$.

Ozaki, Y., McClure, W. F., Christy, A. A. (2007) Nearinfrared spectroscopy in Food Science and Technology, John Wiley \& Sons, New Jersey.

Porep, J. U., Kammerer, D. R., Carle, R. (2015) On-line application of near infrared (NIR) spectroscopy in food production. Trends in Food Science \& Technology, 46 211-230.

Provedbena uredba Komisije (EU) br. 828/2014 od 30 . srpnja 2014. o zahtjevima za informiranje potrošača o odsutnosti ili smanjenoj prisutnosti glutena u hrani. Službeni list Europske unije, 228 Strasbourg.

Sapone, A., Bai, J. C., Ciacci, C., Dolinsek, J., Green, P. H., Hadjivassiliou, M., Kaukinen, K., Rostami, K., Sanders, D. S., Schumann, M., Ullrich, R., Villalta, D., Volta, U., Catassi, C., Fasano, A. (2012) Spectrum of gluten - related disorders: consensus on new nomenclature and classification. BMC Medicine, 1013 .

Scherf, K. A., Koehler, P., Wieser, H. (2016) Gluten and wheat sensitivities - An overview. Journal of Cereal Science, $672-11$.

Verma, A. K., Gatti, S., Galezzi, T., Monachesi, C., Padella, L., Del Baldo, G., Annibali, R., Lionetti, E., Catassi, C. (2017) Gluten Contamination in Naturally or Labeled GlutenFree Products Marketed in Italy. Nutrients, 9115.

Wieser, H. (2007) Chemistry of gluten proteins. Food Microbiology, 24 115-119.

Williams, PC (1987) Variables affecting near-infrared reflectance spectroscopic analysis. Pages 143-167 in: Near Infrared Technology in the Agriculture and Food Industries. 1st Ed. P.Williams and K.Norris, Eds. American Association of Cereal Chemists, St. Paul, MN. 